\section{Economic theories of dictatorship}

\section{Alexandre Debs}

$\mathrm{P}$ olitical and economic life are closely linked. On the one hand, economic resources affect the way that political conflict is resolved. We may ask: which politicians or pieces of legislation are successful given the influence of lobbying and vote-buying? When are democracies or dictatorships stable as a function of income, income inequality, or endowment in natural resources? On the other hand, political institutions affect economic outcomes. We may ask: how does the process of the selection of the executive (democracy vs. dictatorship, parliamentary vs. presidential democracy) affect the provision of public goods, corruption, or growth?

Political scientists and economists have branched out of their traditional fields to tackle these questions. Historically, much more attention has been paid to the study of democracies. Starting with the work of J.A. Schumpeter and A. Downs, we have seen the emergence of economic theories of democracy. According to this view, we should study politicians in a democracy much like firms in the marketplace. Politicians compete for votes in the same way that firms compete for consumers: the former strive to get elected, the latter aim to maximize profits. In both processes, we should understand that the "product" that they offer, a platform for the politician and a good or service for the firm, are mere means to achieve their end. In other words, politicians do not care about the platform that they pick and freely adapt their message so as to ensure their election.

Analyzing democracies with such an economic model in mind has proven very useful, giving birth to the so-called Rochester School of political science, spearheaded by William Riker in the 1960s. ${ }^{1}$ This approach has been slow to expand to the study of dictatorships, but there is a recent and expanding literature on the subject. The goal of this essay is to review recent advances in what we may call economic theories of dictatorships. More specifically, this article focuses on studies using game theory to study the macroeconomy of dictatorships. To be clear, game theory assumes that actors behave rationally and take into account the strategic effect of their behavior on other actors. As a general feature, it strives to present a simplified version of real life so as to highlight salient tensions and interactions. As a result, it leaves out some aspects of the real world and, as we evaluate its usefulness, it is important to determine whether too much is lost in the exercise. The following pages discuss what we have learned from economic theories of dictatorship and highlight avenues for future research. The essay proceeds as follows. The first section focuses on the effect of economic resources on the stability of dictatorships. The second considers the political factors affecting the economic performance of dictatorships. And the third reflects on the general usefulness of economic theories of dictatorship, with an application to foreign relations.
Economic foundations of dictatorships

When considering how economic variables affect the transition to democracy, a long-standing answer is captured in the modernization hypothesis according to which economic development spurs political development (from dictatorship to democracy). ${ }^{2}$ As a guide for foreign policy, the hypothesis suggests that short-term security concerns could justify supporting dictators around the world, and if we care to spread democracy, it will follow naturally from development.

While interesting, the modernization hypothesis has some drawbacks. Empirically, the theory finds weak support. Looking at the 1950-1990 period, Przeworski and Limongi conclude that there is no evidence that greater income facilitates the transition to democracy. Instead, it appears that greater income improves the stability of democracies. But Boix and Stoix argue that focusing on the post-World War II might skew the analysis, since many relatively rich countries democratized before 1950. Taking the sample back to 1850 , they show that income increases the transition from dictatorship to democracy. ${ }^{3}$

The debate could have been settled, but recent authors argue that even 1850 might not be sufficiently early! Some countries experienced industrialization and accelerated growth prior to 1850 and while economic growth could have preceded democracy, it may not have caused it. Instead, they could have both been determined by earlier events in history. Acemoglu and co-authors raise that possibility and show that if we control for the fact that countries entered different development paths, there is no effect of income on democracy between 1875 and 2000. What could be such development paths? For former European colonies, it could have been the environment at the time of European settlement. If settlers arrived in an area of high indigenous population density, they preferred to set up repressive and extractive institutions, which helped their political and economic survival in the short-run but hurt both growth and democracy in the long-run. ${ }^{4}$

This would appear disappointing from a policy perspective: what can we do, today, to change development paths? But we should not forget that the argument bestows a central role to institutions, which can indeed be changed. Moreover, they make us think harder about the mechanism through which institutions are set: who can change institutions, and what are their preferences and constraints? 
Coincidentally, the two most prominent economic theories of dictatorship, by Acemoglu and Robinson and by Boix, tackle these questions in a similar way, sifting through the complexity of politics to focus on conflict between two groups, the rich and the poor. ${ }^{5}$

Exit income and enter inequality as the foundation of economic theories of dictatorship and democracy. Conceptually, this is potentially a more fruitful approach to understanding the stability of dictatorships than simply income. Why would greater income threaten dictatorships, according to the modernization hypothesis? Loosely speaking, according to the modernization hypothesis, as income grows, citizens are more likely to be enlightened, able to make rational decisions, and less vulnerable to extreme ideologies. Perhaps so, but they may also be happier with the current regime if it allows for a higher standard of living. What probably matters is the distribution of resources in society. And it is a defensible assumption that the group of politically powerful citizens is rich, if only because many of the restrictions on voting rights were based on land ownership.

The question then is: how does income inequality affect the stability of regimes? How can politically excluded groups credibly threaten the elites of violently overthrowing their regime? Given the destruction caused by revolutions, why could the elites not always buy off the opposition? Acemoglu and Robinson, and Boix, answer this question in their own way, each focusing on one of two standard problems in negotiating peaceful settlements: commitment problems and asymmetric information. $^{6}$

In the Acemoglu and Robinson model, the threat of revolution materializes because of commitment problems. For them, there is a fundamental difference between policies and institutions, in that the former can be changed easily by the executive, while the latter are more durable. The rich can offer money to the poor (a policy), but if they do not concede political power through democracy (an institution), the poor understand that this promise is not credible if they cannot consistently threaten to overthrow the dictatorship (a reasonable assumption given how difficult it is to solve their collective action problem). If the cost of mounting a revolution is fixed and independent of inequality, then there is a window of intermediate levels of inequality where a policy is not sufficient to stave off a revolution, but an institutional change (democracy) is. If we also allow the elites to prevent a revolution through repression, and if we model repression appropriately, we get an inverted U-shaped relation between inequality and democracy. At low levels of inequality, dictatorship survives with sufficient policy concessions to the poor. At intermediate levels, the elites democratize because policy concessions are no longer sufficient and repression is too costly. At high levels, the elites repress the poor. They support their argument with detailed case studies.

In the Boix story, violence can occur because of asymmetric information: the excluded group is uncertain about the strength of the government and may attack if it believes that the government is weak and did not make sufficient concessions. The prediction of the model is as follows. At low levels of inequality, democracy is relatively costless for the elites and all governments democratize. At higher levels of inequality, there is an equilibrium where only weak governments find it profitable to democratize, since they face a greater cost of repression than strong governments. If the poor observe that the government did not democratize, they infer that the government is strong and refrain from revolution. Boix then concludes that there is a decreasing relationship between inequality and democracy and argues that this relationship obtains in the data, looking at the period from 1950 to 1990 .

Taking a step back, both Acemoglu and Robinson, and Boix, clarify the relationship between conflict (or inequality) and regime change, but given the different conclusions, it is natural to ask to what extent the conclusions depend on the particular game and functional forms. Theoretically, if inequality increases the stakes of holding office, why should it favor the group in power or the excluded group, if they both exert greater effort to gain power? This argument, and a more general theoretical critique, is found in Houle. Interestingly, he finds little support for either the inverted U-shaped or decreasing relationship, using a measure of inequality which, he argues, is more appropriate than that of Boix.?

While the empirical debate on the role of inequality continues, we can try to understand the effect of other economic factors on the stability of dictatorships. According to many scholars, one such factor concerns the supply of natural resources. The possibility that there is a resource "curse," i.e., that the blessing of natural resources hurts political development, seems appropriate given the incidence of dictatorship in many oil-rich countries, for example in the Arabian peninsula. But many stable democracies are resource-rich (e.g., Australia, Norway, Canada) and some would argue that, until recently, Venezuela was among the most stable democracies in Latin America because of its supply of oil. How do we account for the empirical evidence? Dunning suggests an answer. In a clever reformulation of the Acemoglu and Robinson baseline model, he shows that if the resource is owned by the government, the supply of oil rents has two effects on the stability of dictatorships. Directly, greater resource rents have an authoritarian effect because they increase the stakes of holding office, which then hurts democratization in a typical Acemoglu and Robinson framework in which, with probability one, the elites can prevent revolution and democracy by repression. Indirectly, however, resource rents have a democratic effect. With more natural resources, the pressure on redistributing private income decreases and the elites' incentive to oppose democratization decreases. Dunning argues, first, that the authoritarian effect becomes more important when natural resources constitute a larger share of national income, so that we observe a curse of resource dependence, not of resource rents per se. Second, he states that the democratic effect increases with inequality. He presents large-sample evidence in favor of these claims between 1960 and 2001. Resource rents may also affect the stability of a dictatorship through the particular institutions that they promote within a dictatorship. In Dunning's argument, natural resources differ from private income 
in that they are owned directly by the state. ${ }^{8}$

Gandhi and Przeworski take a similar starting point and suggest that a dictator may need to elicit less cooperation from society if the economy is dependent on natural resources. If legislatures lead to policy concessions and generate greater cooperation in response, then a dictator is less likely to allow for opposition parties to join a legislature if the country is resource-rich. Examining dictatorships between 1946 and 1996, they provide evidence in support of this hypothesis. ${ }^{9}$

\section{Economic performance of dictatorships}

If institutions created by a dictator may affect macroeconomic performance, it is then interesting to ask about the reverse relationship: what is the effect of dictatorial institutions on economic performance? Arguably the most important starting point is Olson's. Taking a long view of history, Olson argues for the economic benefit of monarchy relative to the political system of nomadic tribes. Illustratively, he calls the monarch a "stationary bandit" (since he owns his territory and plans to cede it to his kin) and the nomad a "roving bandit." He argues that stationary bandits have the greater incentive to encourage growth, through moderate taxes, generous investment, and the protection of private investments because they care about economic performance over a longer time period. ${ }^{10}$

This argument is enlightening if we take a long view of history, but in the modern era, there are many examples of long-lived dictators who preside over troubled economies. The question then is why dictators stay in power despite poor growth. Unfortunately, Olson's framework cannot directly answer that question because it assumes that tenure is independent of policies. Debs argues that once we take into account the effect of a dictator's policies on his tenure, it may well be that a dictator remains in power because of poor growth. Indeed, if we study the replacement of leaders seriously, we notice that dictators typically tend to be replaced by members of their own government. ${ }^{11}$ This is no surprise because dictators monopolize the reins of power and, if they do not purge them, co-opt skilled politicians. But experienced politicians represent the potential figureheads around which an opposition can rally. The dictator thus faces a genuine trade-off between political survival and economic growth. ${ }^{12}$ Because he cannot make all economic decisions, he must delegate some authority to members of his state. Yet with such freedom of action, these members of the state can claim credit for successful economic policies. In order to prevent them from revealing their aptitude for economic decisionmaking, the dictator may offer them perverse incentives. This, practically, could mean that a dictator would grant his underlings short and uncertain tenure across a variety of location (as in Mughal India, the Ottoman empire, and Zaire under Mobutu). Here, the dictator turns his underlings into a band of "roving bandits," so to speak, and undermines their incentive to encourage growth. This comes at a disastrous cost to the economy, but provides the benefit of preventing them from building their own support base.
Taking this logic one step further, Debs also shows that dictators may benefit from undertaking wasteful projects themselves. The reason is that this could obfuscate any underling's attempt to signal his type. More precisely, groups of citizens look to members of the state as possible replacements to the current dictator and prefer to rise up for a competent insider. Now it could be that, if the dictator makes efficient economic decisions, only competent members of the government want to replace him, since the economic surplus that they generate, once in office, is sufficiently large. To forestall this possibility, the dictator could ensure his survival by wasting resources. By decreasing the payoff of all members of the state under his rule, underlings are dissatisfied and would want to replace him. But in this case, claims of competence cannot be trusted and the leader stays in power. ${ }^{13}$

The models of Debs predict that dictators have the proper incentives to encourage growth when they are either very weak or very strong militarily, but not when of intermediate strength. The prediction appears consistent with the case study evidence. Mughal India, for example, between the reign of Akbar (1556-1605) and Aurangzeb (1658-1707), went from its economic golden age, during the reign of a militarily successful leader who greatly expanded the frontiers of the empire, to its economic decay, with the rule of a weaker emperor who was mired in the costly Maratha wars After Aurangzeb, emperors were even weaker, particularly given the increased European presence, while the economy seems to have experienced a relatively bright period. $^{14}$

In an insightful study, Besley and Kudamatsu take a different approach. In their model, only the dictator makes economic decisions as a public official and he is either kept in office or replaced by a "selectorate" (a clique around the leader). They argue that growth ensues when the selectorate can replace a dictator with relative ease without running the risk of losing their political advantage. In other words, weak leaders, relative to the selectorate, preside over growth, which is positively correlated with leadership turnover. Using the Polity IV data set (1800-2007), they present evidence in support of their hypothesis. ${ }^{15}$ We learn that by analyzing the incentives of leaders to remain in power, we may find that they have perverse incentives to encourage growth.

Discussion, with an application to foreign relations

To assess whether game-theoretic tools are successfully applied to the study of dictatorships, one requirement would be to assess whether scholars have identified the key political actors and accurately described their interaction. If democracy is defined by a competitive struggle for people's votes, then what are the key characteristics of dictatorships?

In all the theories sketched above, there is a group that is politically excluded and does not have a nonviolent way of expressing its preferences. In the Acemoglu and Robinson, and Boix models, the key fault line lies between the rich and the poor. (In 
some cases, though, the key fault line could fall along ethnic lines. ${ }^{16}$ ) It may also be helpful to uncover agency relations within the group in power, as do Debs and Besley and Kudamatsu. ${ }^{17}$ Looking more closely, one question would be to ask whether there are details about the particular institutions that keep a dictator in office and that affect political and economic outcomes. Geddes offers perhaps the most influential study in that vein, categorizing countries depending on whether the inner circle of the dictator consists of members of the military (military dictatorship), of members of a single-party (single-party dictatorship), or if power is concentrated in the hands of the ruler (personalist dictatorship). He argues that if the inner circle around a leader is a group of military officers, then such regimes are less stable because military officers place a high value on upholding national unity and will likely give up power in order to avoid a civil war. Therefore, if we expect economic crises to question the legitimacy of a regime, and if crises arrive at exogenous rates, military regimes should be quicker to fall. For data for 1946 to 1998, Geddes finds evidence in support of her hypothesis. $^{18}$

This typology can also be used to study the reverse relationship, i.e., the effect of regime type on economic performance. Wright argues that the economic effect of legislatures may vary because legislatures serve different purposes. If they serve as a commitment by the dictator not to expropriate private investors, then they can encourage growth. If they serve to split off the opposition, then they can hurt growth. Wright argues that the structure of the economy and the base of power of a dictatorship determine the purpose that a legislature plays. In personalist dictatorships, they are used to split off the opposition, rewarding and punishing elites who challenge the ruler. Wright finds evidence that legislatures hurt growth in personalist dictatorships and encourage growth in military and single-party dictatorships. ${ }^{19}$

Finally, we can build on these typologies of dictatorships and our definitions of democracy to reassess our understanding of the domestic determinants of foreign policy. In particular, consider the democratic peace hypothesis, the finding that democracies rarely, if ever, fight wars against each other. ${ }^{20}$ This finding has been recognized as the closet thing to an empirical law in international relations and has served as an inspiration for American foreign policymaking since President Clinton. Yet a convincing explanation of the finding is still lacking. ${ }^{21}$

The typical starting point is to assume that democrats are more accountable than dictators, that losing a war represents a policy failure and therefore that democrats only fight the wars that they are likely to win, so that two democracies are unlikely to fight one another. One challenge in building such an explanation is that the evidence suggests that the war outcome has a greater effect on the tenure of dictators, not democrats. For a democrat, defeat or victory in war does not affect the hazard rate of losing office, while for a dictator defeat significantly reduces tenure in office and victory significantly increases tenure in office. Perhaps dictators are not competing for votes, but they may be accountable to another constituency. The other piece of information, a complicating factor, is that the democrats actually have less to lose (in economic terms and otherwise) from losing office. For example, they can find lucrative employment as consultants or speakers. In contrast, dictators are much more likely to be exiled, jailed, or killed after leaving office. If we believe that democrats are more likely to be punished as a function of a war outcome, but that the punishment is less serious, it is difficult to determine whether democrats or dictators are more biased toward war.

Building on the economic theory of democracy and testing their theoretical result within the sample of dictatorships, Debs and Goemans suggest an explanation for the democratic peace hypothesis that circumvents these difficulties. Recall that in a democracy, the executive is chosen through competitive struggle for people's votes. Voting is a relatively cheap procedure to replace a leader, so that he may be in general more accountable than otherwise. But another feature of voting is that its cost is not much affected by the military power of the leader. The replacement of dictators, typically done by threat or use of force, is largely affected by their military power and, thus, by the outcome of a war. Therefore, taking such a view of the economic theory of democracy, we may rationalize why the survival of dictators is more affected by the war outcome. ${ }^{22}$

Taking this one step further, we can explain why democrats are unlikely to fight wars against one another. If victory is associated with a larger slice of an international pie than defeat, and if war outcomes are informative about the effect of peaceful concessions on a leader's tenure, then we conclude that the survival of dictators is more sensitive to peaceful concessions. Given that they also have more to lose from losing office, dictators are less accommodating partners in peaceful bargaining, and we should see democrats get involved in fewer wars, especially against each other. Debs and Goemans test the logic of the theory, looking at the sample of dictatorships between 1946 and 1996, and find support for it. Leaders who have the most to lose from leaving office (i.e., military dictators) are most likely to get involved in wars.

Therefore, we see that in terms of understanding foreign policy, there are some rewards in unpacking the relationship between members of the ruling elite. In general, economic theories of dictatorships should strive to strike the proper balance between simplicity and a richer match with the real world so as to allow for possible extensions and to generate useful predictions. This determination, of course, depends on the question at hand. Needless to say, much work remains to be done, but the approach offers promising avenues for future research.

Notes

Alexandre Debs is Assistant Professor of Political Science at Yale University, New Haven, CT, U.S.A. He may be reached at alexandre.debs@yale.edu.

1. See Amadae and Bueno de Mesquita (1999). 


\section{Lipset (1959).}

3. Przeworski and Limongi (1997); Boix and Stokes (2003).

4. Acemoglu, et al. (2008).

5. Acemoglu and Robinson (2000; 2006); Boix (2003).

6. Fearon (1995).

7. Houle (2009).

8. Dunning (2008)

9. Gandhi and Przeworski (2006). There is a growing literature on the effect of legislatures on the stability of dictatorships, which cannot be reviewed here. See, e.g., Lust-Okar (2004); Boix and Svolik (2008); as well as Myerson (2008).

\section{Olson (1993).}

11. Debs (2008a); see also Svolik (2008)

12. See also Egorov and Sonin (2009) for a related framework. In that model, competent viziers can discriminate against potential coup-plotters, making them risky subordinates for the dictator. In the model discussed in the text, viziers represent the potential successors of dictators and let them take an economic decision (i.e., they decide whether to make an investment), studying the effect of the dictator's concern for survival on economic efficiency (i.e., whether the investment takes place).

\section{Debs (2008b).}

14. Marshall (2003).

\section{Besley and Kudamatsu (2007).}

16. See Padro-i-Miquel (2007) for the argument that ethnic divisions could undermine economic performance. In short, citizens may be sufficiently afraid of the rule of another ethnic group so that they could tolerate very low levels of performance from a leader of their own group. (Besley and Kudamatsu, build on this model to make their own argument.) See also Collier (2009) for an excellent review of recent studies on the political economy of weak democracies, detailing how elections are not sufficient to generate public goods or reduce political violence.
17. Or one could model a dictatorship as a self-sustaining coalition, whose members can violently eliminate one another. See Acemoglu, Egorov, and Sonin (2008)

18. Geddes (1999).

19. Wright (2008).

20. Russett (forthcoming)

21. It has long been argued that economic variables, such as trade, have an effect on conflict (Polachak, 2007). Some even claim that the causal effect attributed to democracy is really due to economic development (Gartzke, 2007). This latter claim is controversial and has not been universally recognized in the literature.

\section{Debs and Goemans (2009).}

\section{References}

Acemoglu, D., G. Egorov, and K. Sonin. 2008. "Coalition Formation in Nondemocracies." Review of Economic Studies. Vol. 75, No. 4, pp. 987-1009.

Acemoglu, D., S. Johnson, J.A. Robinson, and P. Yared. 2008. "Income and Democracy." American Economic Review. Vol. 98, No. 3, pp. 808-842.

Acemoglu, D. and J.A. Robinson. 2000. "Why Did the West Extend the Franchise? Growth, Inequality, and Democracy in Historical Perspective." Quarterly Journal of Economics. Vol. 115, No. 4, pp. 683-693.

Acemoglu, D. and J.A. Robinson. 2006. Economic Origins of Dictatorship and Democracy. Cambridge, U.K.: Cambridge University Press.

Amadae, S.M. and B. Bueno de Mesquita. 1999. "The Rochester School: The Origins of Positive Political Theory." Annual Review of Political Science. Vol. 2, pp. 269-295.

Besley, T. and M. Kudamatsu. 2007. "Making Autocracy Work.” Mimeo. London: London School of Economics.

Boix, C. 2003. Democracy and Redistribution. Cambridge, U.K.: Cambridge University Press.

Boix, C. and S.C. Stokes. 2003. "Endogenous Democratization.” World Politics. Vol. 55 , No. 4 , pp. 517-549.

Boix, C. and M. Svolik. 2008. "Institutions and Power-sharing in Dictatorships." Mimeo. University of Illinois at Urbana-Champaign.

Collier, P. 2009. Wars, Guns, and Votes: Democracy in Dangerous Places. New York: Harper Collins.

Debs, A. 2008a. "Political Strength and Economic Efficiency in a Multi-Agent State.' Mimeo. University of Rochester. 
Debs, A. 2008b. “The Wheel of Fortune: Agency Problems in Dictatorships.” Mimeo. University of Rochester.

Debs, A. and H.E. Goemans. 2009. "The Relationship between Regime Type, the Fate of Leaders and War." Mimeo. University of Rochester.

Downs, A. 1957. An Economic Theory of Democracy. New York, N. Y.: Harper.

Dunning, T. 2008. Crude Democracy: Natural Resource Wealth and Political Regimes. Cambridge, U.K.: Cambridge University Press.

Egorov, G. and K. Sonin. 2009. "Dictators and their Viziers: Endogeneizing the Loyalty-Competence Trade-Off." Journal of the European Economic Association (forthcoming).

Fearon, J.D. 1995. "Rationalist Explanations for War.” International Organization. Vol. 49, No. 3, pp. 379-414.

Gartzke, E. 2007. “The Capitalist Peace.” American Journal of Political Science. Vol. 51, No. 1, pp. 166-191.

Geddes, B. 1999. "What Do We Know About Democratization After Twenty Years?" Annual Review of Political Science. Vol. 2, pp. 115-144.

Houle, C. 2009. "Inequality and Democracy: Why Inequality Harms Consolidation But Does Not Affect Democratization.” Mimeo. University of Rochester.

Jaggers, K. and T.R. Gurr. 1995. "Tracking Democracy's Third Wave with the Polity III Data." Journal of Peace Research. Vol. 32, No. 4, pp. 469-482.

Lipset, S.M. 1959. "Some Social Requisites of Democracy: Economic Development and Political Legitimacy." American Political Science Review. Vol. 53, No. 1, pp. 69-105.

Lust-Okar, E. 2004. "Divided They Rule: The Management and Manipulation of Political Opposition.” Comparative Politics. Vol. 36, No. 2, pp. 159-179.

Marshall, P.J., ed. 2003. The Eighteenth Century in Indian History: Evolution or Revolution? New York, N.Y.: Oxford University Press.

Myerson, R.B. 2008. "The Autocrat's Credibility Problem and Foundations of the Constitutional State." American Political Science Review. Vol. 35, No. 2, pp. 125-139.

Olson, M. 1993. "Dictatorship, Democracy, and Development." American Political Science Review. Vol. 87, No. 3, pp. 567-576.

Padro-i-Miquel, G. 2007. "The Control of Politicians in Divided Societies: The Politics of Fear.” Review of Economic Studies. Vol. 74, No. 4, pp. 1259-1274.

Przeworski, A. and F. Limongi. 1997. "Modernization: Theories and Facts." World Politics. Vol. 49 No. 2, pp. 155-183.

Russett, B. Forthcoming. "Democratic Peace." In Nigel Young, ed. International Encyclopedia of Peace. Oxford: Oxford University Press.

Schumpeter, J.A. 1950. Capitalism, Socialism, and Democracy. 3rd edition. New York, N.Y.: Harper \& Brothers Publishers.

Polachak, S.W. 2007. "How Trade Affects International Interactions." The Economics of Peace and Security Journal. Vol. 2, No. 2, pp. 59-68.
Svolik, M. 2009. "Power-sharing and Leadership Dynamics in Authoritarian Regimes." American Journal of Political Science. Vol. 53, No. 2, pp. 477-494.

Wright, J. "Do Authoritarian Institutions Constrain? How Legislatures Affect Economic Growth and Investment." American Journal of Political Science. Vol. 52, No. 2, pp. 322-343. 